Saudi Journal of Business and Management Studies Abbreviated Key Title: Saudi J Bus Manag Stud ISSN 2415-6663 (Print) |ISSN 2415-6671 (Online) Scholars Middle East Publishers, Dubai, United Arab Emirates Journal homepage: https://saudijournals.com

\title{
Proposed Application of Activity Based Budgeting (ABB) Method in Natural Gas Usage Cost Management on Frits Production (Case Study PT XYZ)
}

\author{
Surya Hadi Kurniawan", Nengzih Nengzih \\ Department of Accounting, Faculty Economic and Business, Universitas Mercu Buana, Jakarta
}

\begin{tabular}{ll}
\hline DOI: $10.36348 /$ sjbms.2020.v05i12.002 & | Received: 19.11 .2020 | Accepted: 28.11 .2020 | Published: 05.12.2020
\end{tabular}

*Corresponding author: Surya Hadi Kurniawan

\section{Abstract}

The implementation of the Modern Management Accounting System provides many benefits, but requires several facilities and adjustments in order to function properly. Activity Based Budgeting (ABB) is a system that is useful for managing the production process by providing deeper insights into production utilization and resource allocation compared to traditional budgeting systems. This paper examines the possibilities, benefits and difficulties that may be faced in implementing the ABB system in the manufacturing process of PT XYZ frits in the Indonesian ceramic industry. This paper uses an experimental approach in the application of ABB at PT XYZ to determine the occurrence of inaccuracies in natural gas charging and to eliminate activities that are not value added. The cost of natural gas in the production of frits products is the largest production cost. The conclusions show that some benefits can be obtained and provide more accurate cost information and non-value added activities, in this case, the reworking, dripping and resmelting processes can be eliminated.

Keywords: Activity Based Budgeting, Natural Gas Costs, Frits, Value added.

Copyright () 2020 The Author(s): This is an open-access article distributed under the terms of the Creative Commons Attribution 4.0 International License (CC BY-NC 4.0) which permits unrestricted use, distribution, and reproduction in any medium for non-commercial use provided the original author and source are credited.

\section{INTRODUCTION}

Anthony and Govindarajan [1] stated that the budget reflects an alignment with the strategic plan, which includes the latest information. If the company operates in an industrial context where environmental changes can be predicted, the company can use a formal and rational process to develop a strategy first, and then design a management control system to implement the strategy. According to Mulyadi [2], disclosing costs are sacrifices of economic resources measured in units of money, which have happened, is happening or which are likely to occur for certain purposes. Costs incurred are influenced by many factors which in turn can affect changes in total costs. These factors are referred to as cost drivers. It has been explained previously that costs arise due to the use of resources for certain purposes. The purpose of using costs is referred to as a cost object; information about this cost behavior is very useful in producing an accurate cost budget. According to Adisaputro and Anggraini [3] suggest that Activity
Based Budgeting (ABB) is a planning and control process of activities that are estimated to produce cost effectiveness in the budget, which is in accordance with the workload forecast and set strategic goals. In line with the research conducted by Santiasih and Nengzih [4] regarding the E-Learning Module Arrangement Budgeting Based on Activity Based Budgeting Model which shows that Employee Cost is the most dominant cost and the Activity-Based Budgeting model provides more accurate information and time allocation of hours. Work every activity that is under capacity and over capacity. This budget approach is useful for overcoming the limitations of conventional budgets that are less focused on customers and less motivating organizational members to make improvements to the processes used to serve customers.

Currently PT XYZ uses a traditional system in determining the cost of goods manufactured, which is to calculate all costs incurred divided by the volume of 
production. The company's losses occurred for two consecutive years when similar industries were growing and the entry of several competitors or competitors indicated an irregularity in PT XYZ. There is also an upward trend in sales of products with low profitability and a downward trend in sales of other products with high profitability. With these losses, this research is supported by the willingness of the management to make changes to the cost calculation system to become Activity Based Budgeting (ABB) with the consideration that Activity Based Budgeting (ABB) can help management present more accurate cost of goods manufactured information because of Activity Based Budgeting. (ABB) can trace costs more thoroughly, not only to the volume of production, but to the activities undertaken to produce the product.

Management realizes that with the use of traditional systems, cost information is not accurate in determining the cost of goods manufactured for each type of product produced because each type of product consumes different resources. To eliminate cross subsidies between overcosted and undercosted products, it is necessary to determine an accurate cost of production for each frit product variant at PT XYZ.

\section{LITERATURE REVIEW}

\subsection{Management Control Systems}

Control is an activity or process to ensure that the company's activities are achieved in accordance with the plans and objectives. Control is a function to ensure that actual work is carried out to achieve goals [5]. Thus a management control system means a means of collecting and applying information to support and coordinate a process of planning, decision-making and control throughout the organization and to mobilize employee behavior [6]. The management control system not only presents a broader definition and includes management accounting or accounting control systems but also includes other controls such as activities, personnel and social affairs.

\subsection{Budget}

According to Hansen and Mowen [7], the budget is a quantitative plan in both monetary and nonmonetary form which is used to translate the company's goals and strategies into operational units. Information that can be obtained from the budget includes the number of products and their selling price for next year. Budget has good characteristics in several different aspects compared to forecasting. According to Hilton [8]. A budget is a detailed plan, expressed in quantitative term that specifies how resources will be acquired and used during a specific period of time. Budgets are usually based on the assumption that positive steps will be taken by the budget compilers so that budget realization is in accordance with the plans that have been prepared. On the other hand, prediction is only a prediction of what will happen without implicating the predictor that he will try to influence the realization. When compared with the characteristics of the budget and forecasts have different characteristics.

\subsection{Activity Based Budgeting}

The focus of Activity-Based Budgeting is to plan activities that are useful for presenting value to customers. For the purpose of this value creation, the budgeting process must begin with defining the goals and strategies of the organization. The goals and strategies that have been set must then be reflected in changes in activities to realize these strategic goals. By using Activity-Based Budgeting, the relationship between strategy and budget becomes clearer.

\section{Three basic principles are contained in this definition}

a. Activity-Based Budgeting focuses on understanding activities and their relationship to achieve strategic goals.

Value-driven planning in Activity-Based Budgeting begins with management defining the vision, mission, strategy and value proposals of the product / service. Strategies are formulated based on customer requirement analysis, market knowledge, and competition to determine the value that can be provided to customers. Through a series of steps, this strategy is defined to support performance attributes that suggest the value of a product / service. The cascading process can be used to articulate how strategy should be reflected in processes and activities.

b. Activity-Based Budgeting focuses on value creation.

Value can be created when the customer is willing to use the product / service. To create value that meets consumer desires (customer requirements). It is necessary to translate the organization's vision into a strategy with defined goals. The targets needed to create value include: (also known as value-driven) [9].
1) Acquire or grow market share (A)
2) Improve sales growth rate (B)
3) Increase Profit Margins (C)
4) Reduce Expenses (D)
5) Reduce Cash Taxes (E)
6) Increase Asset Productivity (F)
7) Reduce Cost of Capital (G)

c. Activity-Based Budgeting is a process that directs all company activities to create company value to create value.

Value-driven planning using Activity-Based Budgeting allows each employee to create value for the organization. This can be achieved through planning and managing projected activities and workloads to meet workload forecasts and strategic objectives. Value driven planning directs the organization to understand the causes of deviations, so that these deviations can be controlled. Value driven planning on activities and business processes that are estimated as the basis for obtaining the necessary resources. It is business 
activities and processes that are an important area of focus for value creation, not costs. The key to the success of a plan or budget is to establish financial and operational accountability for achieving the organization's vision and strategy. Value driven planning processes link operational work to financial processes.

\section{METHODOLOGY}

The analytical method used in this research is taxonomic analysis. Taxonomic analysis is describing the selected domains in more detail to determine their internal structure, which is carried out through more focused observations [10]. The focus of the analysis used in this study consists of two analyzes, namely budgeting analysis based on the incremental budgeting approach and the Activity Based Budgeting approach, which are described as follows:

1) Analysis of the incremental budgeting approach

a) Planning for the cost of using natural gas in 2018 , based on the cost of similar work in the previous year.

b) Evaluation of the incremental budgeting approach.

2) Analysis of the Activity Based Budgeting approach

a) Estimated size of the planned revenue or sales from PT XYZ obtained in 2018.

b) Breakdown of all activities related to frits production work, along with the estimated work process time for each of these activities. Each process has details of its own activities related to the use of natural gas. c) Calculating the cost of resources for each of the main activities in connection with the completion of production of frits. So that it is clear that the costs for each planned activity will be carried out.

d) After obtaining the costs for each activity, then these costs are allocated to the cost of the product / output. This will give the total costs required to complete the frits production.

e) Inventory of all available resources related to frit production. Each resource is organized based on the unit and cost basis of each resource.

f) Estimated total resource requirements for each of the main activities.

g) Execution of resource capacity settings that are not needed in work process activities.

h) Evaluation of hourly capacity costs for each activity, so that the calculation of resource costs for future periods can be carried out.

3) Minimizing the shortcomings of the incremental budgeting method through the use of the proposed Activity Based Budgeting

\section{RESULT AND ANALYSIS}

In Table 4.2 , it can be shown that the sales budget increased by $8.1 \%$ from 46,975 MT in 2019 to $50,800 \mathrm{MT}$ in 2020. And the portion of the manufacturing cost or Bill of Operation (BOO) is budgeted to increase $7.5 \%$ from USD 7,093,150 to USD $7,627,050$. In other words, the BOO rate budget has decreased by $1 \%$ from USD 151 / MT to USD 149.6 / MT.

\begin{tabular}{|l|r|r|r|}
\hline \multicolumn{3}{|l|}{ Total Manufacturing Cost / Bill of Operation } \\
\hline In USD & Actual 2019 & Budget 2020 & Increased \% \\
\hline Direct Labor cost & 685,305 & 753,835 & $10.0 \%$ \\
Depreciation cost & & & \\
$\quad$ Weighing and equipment & 164,003 & 167,283 & $2.0 \%$ \\
$\quad$ Smelter machines & $1,535,800$ & $1,566,517$ & $2.0 \%$ \\
$\quad$ Dryer and Packing machine & 327,007 & 333,547 & $2.0 \%$ \\
Energy Cost & & & \\
$\quad$ Natural Gas & $2,591,851$ & $2,851,037$ & $10.0 \%$ \\
$\quad$ Oxygen & $1,128,799$ & $1,241,679$ & $10.0 \%$ \\
$\quad$ Electricity & 338,996 & 372,896 & $10.0 \%$ \\
Packaging Cost & 321,389 & 340,255 & $5.9 \%$ \\
Total $\quad$ & & \\
$\quad$ BOO rate & $\mathbf{7 , 0 9 3 , 1 5 0}$ & $\mathbf{7 , 6 2 7 , 0 5 0}$ & $7.5 \%$ \\
$\quad$ Sales MT & $\mathbf{1 5 1 . 0 0}$ & $\mathbf{1 4 9 . 5 5}$ & $-1.0 \%$ \\
& & & \\
\hline
\end{tabular}

With the feature costing method that has been running at PT XYZ, the BOO rate can be described per MT as follows. 


\begin{tabular}{|l|r|l|l|}
\hline Manufacturing Cost & & Unit cost in & \\
\hline USD/MT & 14.8 & \\
\hline Weighing Cost & & 3.3 & \\
\hline Electricity & & 7.3 & \\
\hline Natural Gas & & 55.9 & \\
\hline Oxygen & & 24.3 & \\
\hline Smelter Cost & & 30.7 & \\
\hline Packaging cost & 6.5 & \\
\hline Packaging material dan support cost & & 6.7 & \\
\hline Total & & 149.55 & \\
\hline
\end{tabular}

The cost allocation process from feature costing becomes based on average activity. Each activity is identified from the amount of labor used, energy costs, namely natural gas, oxygen, electricity used in activities, depreciation costs in activities, and supporting materials. The stages are 1. Determine the features of the product, 2. Determine the activity path associated with each product feature, 3 . Determine the cost of each activity, 4 . Determine the characteristics of the product that will cause the production process to be different, 5. Determine the effect of product characteristics causing differences in the production process, 6. Linking product features and characteristics to the product, 7. Adjusting activity costs based on product features and characteristics.
In table 4:14 it can be shown that there are 3 activities, namely Rework / Return, Dripping and Resmelting which are classified as non-value added activities. Total for this non-value added activity was USD 431,216. Value added activity is an activity to keep the company or its parts in business. Some valueadded activities are activities that must be carried out (required activities), namely activities that are required by regulations issued by the competent authority. Several other value-adding activities are discretionary activities.

Non value added activity is an activity that is not needed to generate value for customers. Activities that do not meet any of the three value-added activity criteria are non-value-adding activities

\begin{tabular}{|l|r|r|r|l|l|l|}
\hline Activities & $\begin{array}{l}\text { Cost/Output } \\
\text { (USD/MT) }\end{array}$ & output in MT & $\begin{array}{l}\text { Cost } \\
\text { activity }\end{array}$ & $\begin{array}{l}\text { Activities } \\
\text { Elimination } \\
\text { target }\end{array}$ & $\begin{array}{l}\text { Target } \\
\text { Cost/output } \\
\text { USD/MT) }\end{array}$ \\
\hline Weighing & 2.01 & 50,800 & 102,108 & & 2.01 \\
\hline Rework/Return & 2.2 & 50,800 & 111,176 & 111,176 & 33.23 \\
\hline Blending & 33.23 & 50,800 & $1,637,284$ & & 98.2 \\
\hline Smelting & 98.2 & 50,800 & $4,988,560$ & & 0 \\
\hline Dripping & 1.2 & 50,800 & 60,960 & 60,960 & 0 \\
\hline Resmelting & 5.1 & 50,800 & 259,080 & 259,080 & 7.64 \\
\hline Packing & 7.64 & 50,800 & 388,112 & & 141.08 \\
\hline Total & 149.55 & & $7,547,280$ & 431,216 & \\
\hline
\end{tabular}

Furthermore, the elimination of activity that does not add value can be included in PT XYZ's Profit and Loss projection. 
Surya Hadi Kurniawan \& Nengzih Nengzih., Saudi J Bus Manag Stud, Dec, 2020; 5(12): 554-560

\begin{tabular}{|c|c|c|c|}
\hline In USD & Value Added & Non Value Added & Total \\
\hline Projected Revenue & $26,714,285$ & & $26,714,285$ \\
\hline Minus Target Profit & $5,547,360$ & & $5,547,360$ \\
\hline \multicolumn{4}{|l|}{ Target Cost/Allowables } \\
\hline Weighing & 102,108 & & 102,108 \\
\hline Rework/Return & 111,176 & 111,176 & 0 \\
\hline Blending & $1,637,284$ & & $1,637,284$ \\
\hline Smelting & $4,984,496$ & & $4,984,496$ \\
\hline Dripping & 60,960 & 60,960 & 0 \\
\hline Resmelting & 259,080 & 259,080 & 0 \\
\hline Packing & 388,112 & & 388,112 \\
\hline Bill Of Materials & $13,325,424$ & & $13,325,424$ \\
\hline Total Cost & $20,868,640$ & 431,216 & $20,437,424$ \\
\hline (Over) Target Cost Gap & & & 431,216 \\
\hline
\end{tabular}

In a detailed working paper, the 13 types of frits products can be described from the identification of costing features and the application of cost based on activities as follows. In the allocation based on feature costing, it can be shown that the over-costed and undercosted products are compared to the traditional application of one $\mathrm{BOO}$ rate. And after the implementation of activity-based cost allocations, the decrease in manufacturing costs is increasingly evident, especially with the elimination of rework, re-smelt and dripping activities.

\begin{tabular}{|c|c|c|c|c|c|c|c|c|c|c|c|c|c|c|c|}
\hline No & Lini Produk & $\begin{array}{c}\text { ABC- } \\
\text { A01 }\end{array}$ & $\begin{array}{c}\text { ABC- } \\
\text { A81 }\end{array}$ & $\begin{array}{c}\text { ABC- } \\
\text { A88 } \\
\end{array}$ & $\begin{array}{c}\text { ABC- } \\
\text { B06 }\end{array}$ & $\begin{array}{c}\text { ABC- } \\
\text { B26 } \\
\end{array}$ & $\begin{array}{c}\text { ABC- } \\
\text { B95 } \\
\end{array}$ & $\begin{array}{l}\text { ABC- } \\
\text { C054 } \\
\end{array}$ & $\begin{array}{l}\text { ABC- } \\
\text { C257 } \\
\end{array}$ & $\begin{array}{l}\text { ABC- } \\
\text { C } 323 \\
\end{array}$ & $\begin{array}{l}\text { ABC- } \\
\text { C611 } \\
\end{array}$ & $\begin{array}{l}\text { ABC- } \\
\text { C637 } \\
\end{array}$ & $\begin{array}{l}\text { ABC- } \\
\text { C707 } \\
\end{array}$ & $\begin{array}{c}\text { ABC- } \\
\text { D31 } \\
\end{array}$ & Total \\
\hline \multicolumn{16}{|c|}{ Activity plan - Feature Costing } \\
\hline & Direct Labor & 15.58 & 15.17 & 15.69 & 14.57 & 14.57 & 15.12 & 15.37 & 12.6 & 12.6 & 15.37 & 15.02 & 15.37 & 15.12 & 192.15 \\
\hline & \begin{tabular}{|l|}
$\begin{array}{l}\text { Weighing } \\
\text { machine }\end{array}$ \\
\end{tabular} & 3.28 & 3.28 & 3.28 & 3.28 & 3.28 & 3.28 & 3.28 & 3.28 & 3.28 & 3.28 & 3.28 & 3.28 & 3.28 & 42.64 \\
\hline & Electricity & 7.25 & 7.25 & 7.25 & 7.25 & 7.25 & 7.25 & 7.25 & 7.65 & 7.65 & 7.25 & 7.25 & 7.25 & 7.25 & 95.05 \\
\hline & Natural Gas & 62.72 & 56.32 & 52.16 & 56.96 & 56.96 & 56.96 & 54.72 & 50.88 & 50.88 & 54.72 & 57.92 & 54.72 & 60.8 & 726.72 \\
\hline & \begin{tabular}{|l|} 
Oxygen \\
\end{tabular} & 26.9 & 26.7 & 28.7 & 26.8 & 26.8 & 26.8 & 21.7 & 18.7 & 18.7 & 21.7 & 26.6 & 21.7 & 24.7 & 316.5 \\
\hline & \begin{tabular}{|l|} 
Smelter \\
machine
\end{tabular} & 34.13 & 32.37 & 34.58 & 29.8 & 29.8 & 32.16 & 33.23 & 21.44 & 21.44 & 33.23 & 31.73 & 33.23 & 32.16 & 399.3 \\
\hline & $\begin{array}{l}\text { Packing } \\
\text { machine }\end{array}$ & 6.54 & 6.54 & 6.54 & 6.54 & 6.54 & 6.54 & 6.54 & 6.54 & 6.54 & 6.54 & 6.54 & 6.54 & 6.54 & 85.02 \\
\hline & $\begin{array}{l}\text { Packing } \\
\text { materials }\end{array}$ & 6.57 & 6.57 & 6.57 & 7.01 & 6.57 & 6.57 & 6.57 & 6.57 & 6.57 & 7.01 & 7.01 & 6.57 & 6.57 & 86.73 \\
\hline & & 162.97 & 154.2 & 154.77 & 152.21 & 151.77 & 154.68 & 148.66 & 127.66 & 127.66 & 149.1 & 155.35 & 148.66 & 156.42 & 1944.11 \\
\hline \multicolumn{16}{|l|}{ Activity cost } \\
\hline & Weighing & 2.01 & 2.01 & 2.01 & 2.01 & 2.01 & 2.01 & 2.01 & 2.01 & 2.01 & 2.01 & 2.01 & 2.01 & 2.01 & 26.13 \\
\hline & Blending & 34.13 & 32.37 & 34.58 & 29.8 & 7.01 & 32.16 & 33.23 & 21.44 & 21.44 & 33.23 & 7.46 & 33.23 & 32.16 & 352.24 \\
\hline & Smelting & 104.44 & 97.43 & 95.79 & 97.57 & 120.36 & 98.12 & 91.03 & 81.82 & 98.22 & 91.03 & 98.78 & 91.03 & 91.03 & 1256.65 \\
\hline & Dripping & 0 & 0 & 0 & 0 & 0 & 0 & 0 & 0 & 0 & 0 & 0 & 0 & 0 & 0 \\
\hline & Packing & 9.28 & 15.74 & 7.64 & 7.64 & 13.3 & 8.26 & 7.64 & 7.64 & 7.64 & 7.64 & 7.64 & 7.64 & 7.64 & 115.34 \\
\hline & & & & & & & & & & & & & & & \\
\hline & & 149.86 & 147.55 & 140.02 & 137.02 & 142.68 & 140.55 & 133.91 & 112.91 & 129.31 & 133.91 & 115.89 & 133.91 & 132.84 & 1750.36 \\
\hline
\end{tabular}

\begin{tabular}{|l|r|r|r|r|r|r|r|r|r|r|r|r|r|r|}
\hline Existing BOO allocation & 149.55 & 149.55 & 149.55 & 149.55 & 149.55 & 149.55 & 149.55 & 149.55 & 149.55 & 149.55 & 149.55 & 149.55 & 149.55 & $1,944.11$ \\
\hline
\end{tabular}

A summary of the differences in the allocation of manufacturing costs before and after the implementation of $\mathrm{ABB}$ is as follows 
Surya Hadi Kurniawan \& Nengzih Nengzih., Saudi J Bus Manag Stud, Dec, 2020; 5(12): 554-560

\begin{tabular}{|c|c|c|c|c|c|c|c|c|c|c|c|c|c|}
\hline \multicolumn{14}{|c|}{ Comparison of Bill of operation with ABB with Existing and Feature costing method (in USD/MT) } \\
\hline & $\begin{array}{c}\text { ABC- } \\
\text { A01 }\end{array}$ & $\begin{array}{c}\text { ABC- } \\
\text { A81 }\end{array}$ & $\begin{array}{c}\text { ABC- } \\
\text { A88 }\end{array}$ & $\begin{array}{c}\text { ABC- } \\
\text { B06 }\end{array}$ & $\begin{array}{c}\text { ABC- } \\
\text { B26 }\end{array}$ & $\begin{array}{c}\text { ABC- } \\
\text { B95 }\end{array}$ & $\begin{array}{l}\text { ABC- } \\
\mathrm{C} 054\end{array}$ & $\begin{array}{l}\text { ABC- } \\
\text { C257 }\end{array}$ & $\begin{array}{l}\text { ABC- } \\
\text { C } 323\end{array}$ & $\begin{array}{l}\text { ABC- } \\
\text { C611 }\end{array}$ & $\begin{array}{l}\text { ABC- } \\
\text { C637 }\end{array}$ & $\begin{array}{l}\text { ABC- } \\
\text { C707 }\end{array}$ & $\begin{array}{c}\text { ABC- } \\
\text { D31 }\end{array}$ \\
\hline Existing/Traditional method (A) & 149.55 & 149.55 & 149.55 & 149.55 & 149.55 & 149.55 & 149.55 & 149.55 & 149.55 & 149.55 & 149.55 & 149.55 & 149.55 \\
\hline Feature Costing (B) & 162.97 & 154.20 & 154.77 & 152.21 & 151.77 & 154.68 & 148.66 & 127.66 & 127.66 & 149.10 & 155.35 & 148.66 & 156.42 \\
\hline ABB Method (C) & 149.86 & 147.55 & 140.02 & 137.02 & 142.68 & 140.55 & 133.91 & 112.91 & 129.31 & 133.91 & 115.89 & 133.91 & 132.84 \\
\hline Difference Existing vs Feature (B-A) & 13.42 & 4.65 & 5.22 & 2.66 & 2.22 & 5.13 & $(0.89)$ & (21.89) & (21.89) & $(0.45)$ & 5.80 & $(0.89)$ & 6.87 \\
\hline in \% & $9.0 \%$ & $3.1 \%$ & $3.5 \%$ & $1.8 \%$ & $1.5 \%$ & $3.4 \%$ & $-0.6 \%$ & $-14.6 \%$ & $-14.6 \%$ & $-0.3 \%$ & $3.9 \%$ & $-0.6 \%$ & $4.6 \%$ \\
\hline Difference Existing vs $A B B(C-A)$ & 0.31 & $(2.00)$ & (9.53) & (12.53) & (6.87) & $(9.00)$ & (15.64) & $(36.64)$ & (20.24) & (15.64) & (33.66) & (15.64) & (16.71) \\
\hline in \% & $0.2 \%$ & $-1.3 \%$ & $-6.4 \%$ & $-8.4 \%$ & $-4.6 \%$ & $-6.0 \%$ & $-10.5 \%$ & $-24.5 \%$ & $-13.5 \%$ & $-10.5 \%$ & $-22.5 \%$ & $-10.5 \%$ & $-11.2 \%$ \\
\hline
\end{tabular}

\section{CONCLUSION}

First, there is a significant change in product costs, especially for the transparent frits type where the cost for natural gas in producing the product is more reflective of the actual situation in accordance with the actual consumption. On the other hand, frits opaque has been enjoying a lower cost of natural gas than it should have been allocated a more precise cost so that the pricing strategy needs to be adjusted. The difference in the use of natural gas costs apart from the amount or quantity of material is also influenced by the nature of the various raw materials, the time and calories of natural gas used the corrosiveness of the raw materials to the smelter machine.

Second, the allocation of natural gas costs with feature costing for the application of $\mathrm{ABB}$ clearly makes the cost of each frit product fairer, fairer and more actual than the allocation of gas costs on a traditional basis, namely by dividing the total cost of natural gas by the total frit production output. The use of Calorimeter and Meter Regulating Station tools is the basis for determining the cost of natural gas for each frit finished goods cost.

Third, PT XYZ can analyze and review the inaccuracies of the pricing strategy so far that it is expected to be able to restore the company's profit level to the right direction. The proposal to implement Activity Based Budgeting (ABB) can reduce and identify non value added activities so that PT XYZ becomes more competitive. This is shown based on $\mathrm{ABB}$ budgeting of several types of frits production, namely opaque, transparent, titanium and others.

After realizing the limitations of the traditional budget approach and costing systems that are currently being carried out, PT XYZ is advised to implement the ABC model and apply the ABB process. Company. The critical nature provided in the $\mathrm{ABB}$ process contained in the $A B C$ model assists the design process in providing the information needed to improve the quality of the time available between manufacturing and procurement so that they can make more informed decisions. Production managers in collaboration with the finance accounting department can budget future product costs based on the Activity Driver Unit Cost, for example the number of production processes, the number of equipment and duration of testing, current support costs can be allocated based on drivers (triggers) including the number of order changes. The uniqueness of the product type and the type of quality audit. In the end, the cost of supporting raw materials is separated into groups to be allocated to the cost of raw materials. This new model consists of four cost elements, namely raw materials, supporting raw materials, production and other support. This consists of 3 cost pools and 13 Activity Drivers as described in 4.15.

The target costing process uses $\mathrm{ABC}$ and $\mathrm{ABB}$ information and is formed from new products and existing products to facilitate life cycle cost management. The target costing process begins with the marketing manager estimating the price of a new product with its salable specifications and functions. Furthermore, the manufacturing or production section locks the target cost or target cost which consists of raw materials and manufacturing activity costs.

Fourth, the company can see the forecast of the number of products that will determine the level of activity. From this information an activity cost can be determined so that the production department has the ability to predict its expenses. This information can also be compared with previous years, and focuses on spending decisions that can be controlled or influenced. The decisions of the operations manager can lead to departmental budgets related to the impact on the product and any gross profit on the product. This is something that the traditional budgeting process cannot do.

All parties involved in the company from the production manager to the design department, including the marketing manager, now have a better understanding of costs so that they can produce better decision making in all areas.

ABB provides critical and important information for strategic and operational matters for the company. The proposal to implement ABB in PT XYZ shows that there are benefits and something good that 
was derived from the application of this ABB. And as more companies develop and change their traditional budgeting processes it is hoped that more success stories and research on $\mathrm{ABB}$ will deepen.

\section{REFERENCE}

1. Anthony, N., Robert dan Govindarajan, V. (2011). Management Control System. Tangerang: Karisma Publishing Group.

2. Mulyadi. (2015). Cost accounting. Yogyakarta: YKPN College of Management.

3. Adisaputro, \& Anggraini. (2011). Business Budget: Analysis, Planning, and Profit Control.. Yogyakarta: UPP STIM YKPN

4. Santiasaih, N. (2015). E-Learning Module Arrangement Budgeting Based on Activity Based Budgeting Model International Journal of Scientific Research and Management (IJRSM)
5. Drury, C. (2018). Management and Cost accounting $\left(10^{\text {th }}\right.$ ed). United Kingdom : Cengage Learning

6. Bhimani, A., Charles, T.H., Srikant, M.D., Madhav, V.R. (2015), Management and Cost Accounting, $6^{\text {th }}$ edition, Pearson Education

7. Hansen. \& Mowen. (2006). Managerial Accounting 8th Edition, Cengage Learning

8. Hilton. (2008). Managerial Accounting: Creating Value in a Dynamic Business Environment 11th Edition, McGraw-Hill Higher Education

9. Brimson, D. A. (1999). Driving Value Using Activity-Based Budgeting 1st Edition, Wiley

10. Abad \& Yanik. (2017). Developing a Model for Activity Based Budgeting and Application on Manufacturing Firms, 5th International Conference on Research Approach In Humanities and Management. 